\title{
Optimization of Supercritical Fluid Extraction of Hydrocarbons from a Contaminated Soil: An Experimental Approach
}

\author{
Ali H. Al-Marzouqi, Abdulrazag Y. Zekri, Adel A. Azzam, and Abdulrahman Y. Alraeesi
}

\begin{abstract}
Soil and sediment contamination with hydrocarbons is an environmental concern, which demands for more efficient remediation techniques. Pure and modified supercritical carbon dioxide $\left(\mathrm{SC} \mathrm{CO}_{2}\right.$ ) was used for the extraction of petroleum hydrocarbons from soil contaminated with crude oil. Effect of $\mathrm{CO}_{2}$ flow rate $(1$ and $4 \mathrm{ml} / \mathrm{min})$, temperature $\left(80\right.$ and $\left.160{ }^{\circ} \mathrm{C}\right)$, pressure $(250$ and $350 \mathrm{bar})$, and addition of $5 \%(\mathrm{v} / \mathrm{v})$ organic solvent (heptane or toluene) on the extraction efficiency and on the composition of extracted hydrocarbons were investigated. The maximum extraction efficiency $(92.26 \%)$ was obtained at $80{ }^{\circ} \mathrm{C}$ and 350 bar corresponding to a modified $\mathrm{CO}_{2}$ with $5 \%(v / v)$ heptane's and $\mathrm{CO}_{2}$ flow rate of $1 \mathrm{ml} / \mathrm{min}$. Extraction efficiency of $\mathrm{CO}_{2}$ increased with pressure and decreased with temperature. Chemical modification of $\mathrm{CO}_{2}$ by adding heptane increased the extraction efficiency. Analysis of the soil after the extraction process shows that pure $\mathrm{SC} \mathrm{CO}_{2}$ was able to remove up to $92.86 \%$ of $\mathrm{TPH}$ in the contaminated soil. In addition, a significant reduction in PAH level was observed. Supercritical fluid extraction proved to be an efficient method for the remediation of hydrocarbon-contaminated soil.
\end{abstract}

Index Terms-Carbon dioxide, extraction, heptane, soil, toluene, supercritical (SC).

\section{INTRODUCTION}

Soil contamination with crude oil and petroleum products is often observed at industrial sites, causing environmental pollution, which can be hazardous to the health of plants, animals, and humans [1]-[6]. The hydrocarbon molecules may contain hazardous complex chemical mixtures such as total petroleum hydrocarbons (TPH), polychlorinated biphenyls (PCBs), and polycyclic aromatic hydrocarbons (PAHs). Removal of such compounds from contaminated sites is an important and challenging problem.

The most important and widely used remediation methods are incineration, thermal desorption, biological remediation, chemical treatment and solvent extraction [7], [8]. Conventional techniques such as landfill disposal, thermal desorption, incineration and liquid solvent extraction are expensive and involve risks associated with air and residual pollution. Biological remediation is a rather slow process, with possible logistic and practical disadvantages. Mohammadi-Sichani et al. indicated that biological treatment were effective in the degradation of petroleum hydrocarbons

Manuscript received January 2, 2019; revised July 22, 2019.

The authors are with United Arab Emirates University, Al-Ain, P.O. Box: 15551, U.A.E. (corresponding author: Abdulrazag Y. Zekri; e-mail: a.zekri@uaeu.ac.ae). contaminated soil after three months [9].

Despite great efforts and expenditure of resources to develop both technically and economically effective cleanup processes for contaminated soils, no widely accepted method has been found and further research is still needed. New methods are therefore being investigated in order to improve the remediation efficiency and lower the costs or the remediation time. Since three decades ago, supercritical fluids (SCFs) have been used as extraction media to remove various types of substances from solid matrices. The unique properties of SCFs that make them technically attractive are their enhanced ability to dissolve organic compounds, an ability, which can be easily tuned by changing temperature and/or pressure, thus changing the fluid properties from gas-like to liquid-like. This sensitivity to temperature and pressure leads to simple solute-solvent separation schemes. Supercritical fluids can have better mass transfer through a porous matrix due to their higher diffusivity than a normal liquid phase, resulting in a faster extraction [10]. Moreover, densities of SCFs are higher than those of normal gases, leading to higher solvent power than gases. Such properties allow the SCFs to dissolve and carry away materials like a liquid but also enter very small pores like a gas. Other attractive features of SCFs include low viscosity and high diffusivity that are essential to reduce mass transfer resistance during the desorption processes. Because of these special characteristics, supercritical fluids are used in extractions, separation, chemical reactions, impregnation, polymer processing, food processing, environmental remediation and pharmaceutical production [11]. The most popular fluid is supercritical carbon dioxide $\left(\mathrm{SC} \mathrm{CO}_{2}\right)$ because it is non-toxic, non-flammable, chemically stable, readily available, inexpensive, environmentally acceptable, and can easily be separated from the products. Although SCF technology has been successfully realized for environmental remediation in the laboratory, its commercialization still lacks the significant technological improvement required in order to reach economic feasibility.

Like other new technologies, SFE technology, utilizing $\mathrm{CO}_{2}$ as a fluid has its specific problems. One of these problems is the limited ability of $\mathrm{SC} \mathrm{CO}_{2}$ to dissolve and separate polar or high molecular weight organic compounds even at very high densities. To increase the efficiency of the SFE process for such compounds, the selectivity and solubilizing power of $\mathrm{SC} \mathrm{CO}_{2}$ can be enhanced by the addition of polar organic compounds, known as modifiers.

Significant research has been carried out in order to study various aspects of contaminant removal by $\mathrm{SC} \mathrm{CO}_{2}$ 
Comprehensive presentations of various aspects on the use of this technology for extraction purpose are available in several critical reviews ([1], [12], [13]) and hundreds of other scientific articles. Pressure, temperature, composition of the crude oil and physicochemical properties of the solid matrix affect the extraction capacity of $\mathrm{SC} \mathrm{CO}_{2}$. Supercritical $\mathrm{CO}_{2}$ has been successfully used for extracting a variety of organic compounds such as polycyclic aromatic hydrocarbons (PAHs) ([14]-[20]), polychlorinated biphenyls (PCBs) ([1], [18], [21]-[24]), pesticides ([25]-[27]), and hydrocarbons ([18], [28]-[33]). The extraction of these compounds was performed from various porous media, such as soils and sediments ([3]-[5], [7], [14], [15], [19], [22], [24])) or rocks ([32], [34]-[37]). These investigators have studied a combination of different parameters such as characteristics of the supercritical fluid (with and without modifier), solid matrix, operating conditions (i.e. temperature, pressure, density, and flow rate), water content and solute physical and chemical properties, in order to find the optimum conditions leading to the highest extraction yield.

Data for $\mathrm{CO}_{2}$ extraction at extremely high pressures and temperatures are scarce in the literature, especially for soil contaminated with crude oil. Al-Marzouqi et al in 2007 showed that $\mathrm{SC} \mathrm{CO}_{2}$ at 300 bar and $120^{\circ} \mathrm{C}$ is able to extract about $70 \%$ of hydrocarbons from a typical UAE soil contaminated with crude oil [33]. Meskar et al. in 2018 employed diesel oil to study the effect of pressure and temperature on the $\mathrm{CO}_{2}$ extraction process [38]. They have concluded that petroleum hydrocarbon removal rates is increasing with pressure at constant temperature, however, increasing temperature did not result in higher PHC removal rates at constant pressure. The objective of the present study was to investigate the ability of pure and modified $\mathrm{CO}_{2}$ under supercritical conditions to remediate soil contaminated with crude oil and achieve higher extraction efficiencies. The effects of $\mathrm{CO}_{2}$ flow rate, temperature, pressure, and modifier (heptane or toluene) on the extraction capacity of the SCF and on the composition of extracted hydrocarbons were investigated. The extent of residual oil in the matrix after SFE was also determined.

\section{EXPERIMENTAL}

\section{A. Material}

Carbon dioxide (purity of 99.995\%) was supplied by Abu Dhabi Oxygen Company. Crude oil (average molecular weight $=281.5 \mathrm{~g} / \mathrm{mole}$ and density $=0.8634 \mathrm{~g} / \mathrm{ml})$ was obtained from Bu Hasa oil field (Abu Dhabi, UAE) and was filtered to remove all sand particles. Hydrocarbon composition of the crude oil used in this study indicates the presence of mainly light and moderate hydrocarbons, i.e. $80 \%$ hydrocarbons less than $\mathrm{C} 20$. The chemical modifiers (n-heptane and toluene) and the organic solvents (dichloromethane and methanol) were of analytical grade with purity $\geq 99 \%$ and were supplied by Sigma Aldrich. Soil samples (bulk density $=1.6 \mathrm{~g} / \mathrm{ml}$ and average particle size $=$ $150 \mu \mathrm{m}$ ) were collected from Sahel oil field, which is near $\mathrm{Bu}$ Hasa oil field in the UAE. The size distribution of the soil sample was: $11 \%$ less than $106 \mu \mathrm{m}, 29.56 \%$ between 106 and
$150 \mu \mathrm{m}, 44.07 \%$ between 150 and $212 \mu \mathrm{m}, 12.52 \%$ between 212 and $300 \mu \mathrm{m}, 2.81 \%$ between 300 and $600 \mu \mathrm{m}, 0.03 \%$ between 600 and $850 \mu \mathrm{m}$, and $0.01 \%$ between 850 to 1180 $\mu \mathrm{m}$. The porosity and permeability of the soil were $35 \%$ and 20.15 Darcy, respectively.

\section{B. Experimental Design}

Extraction of hydrocarbons with SCFs from contaminated soil was carried out by following the full factorial experimental design with four factors. The factors investigated were (in parentheses are the variable coded values): pressure with values of $250(-1)$ and 350 (1) bar, temperature $80(-1)$ and $160(1){ }^{\circ} \mathrm{C}$, flow rate of $1(-1)$ and 4 (1) $\mathrm{ml} / \mathrm{min}$ and fluid type pure $\mathrm{SC} \mathrm{CO}_{2}(1)$, modified $\mathrm{SC} \mathrm{CO}_{2}$ with $5 \%(\mathrm{v} / \mathrm{v})$ toluene (2) and modified $\mathrm{SC} \mathrm{CO}_{2}$ with $5 \%(\mathrm{v} / \mathrm{v})$ n-heptane (3). This design was used to find the best conditions for the extraction of oil from contaminated soil and to study the effects of all factors (temperature, pressure, flow rate of SCF, and type of modifier) on the extraction efficiency. The total number of factor-level combinations was 24. Each experiment was repeated twice, resulting in a total number of 48 experiments. Experiments were run in random order to eliminate various types of biases due to uncontrolled nuisance factors. The statistical analysis was performed using the statistical package SPSS (SPSS inc., Version 15.0). Table I shows the order of the experiments and the factor-level combinations. All the statistical analyses of the effects of variables on the extraction efficiency were performed using a multi-way analysis of variance (ANOVA) with two replications per cell. Also, whenever applicable, Tukey's HSD Test was used to identify the factor-level combinations that yield the extraction efficiency. A level of $5 \%$ was used as the cut-off value for statistical significance.

\section{Experimental Apparatus}

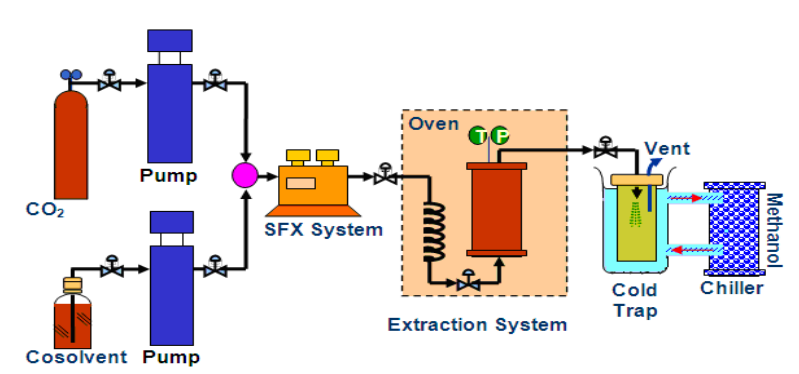

Fig 1. Experiment setup for supercritical fluid extraction.

Fig. 1 shows schematic diagram of the supercritical fluid extraction system used in this study. The experimental setup consisted of a 260-ml capacity syringe pump and a controller system (ISCO 260D), a 100-ml stainless steel extraction chamber (DBR-JEFRI 100-10-BE), and a cold trap as described earlier [33]. The extraction chamber was kept in an air-circulating oven (Memmert ULE 400) with a temperature control ranging from $30-250{ }^{\circ} \mathrm{C}$. Pressure within the extraction chamber was measured and controlled by the ISCO system. The temperature of the extraction chamber was measured by a J-type thermocouple (Omega model JMTSS-062-U-12) connected to a thermometer (Barnant, model 692-0230) and controlled by the oven. A micro-metering valve (HIP 15-12AF1-V) was used as the expansion valve at the exit of the extraction chamber to 
achieve a good control of the flow rate. Circulating methanol at $-15{ }^{\circ} \mathrm{C}$ was used as a cold trap to separate $\mathrm{CO}_{2}$ from other components of the mixture.

TABLE I: EXPERIMENTAL ORDER AND FACTOR-LEVEL COMBINATIONS

\begin{tabular}{|c|c|c|c|c|}
\hline $\begin{array}{l}\text { Experiment } \\
\text { order }\end{array}$ & Temperature & Pressure & $\begin{array}{l}\text { Flow } \\
\text { Rate }\end{array}$ & Fluid Type \\
\hline 10 & -1 & 1 & 1 & 1 \\
\hline 34 & -1 & 1 & 1 & 1 \\
\hline 43 & 1 & 1 & -1 & 1 \\
\hline 40 & 1 & -1 & 1 & 1 \\
\hline 46 & 1 & 1 & 1 & 1 \\
\hline 28 & -1 & -1 & 1 & 1 \\
\hline 25 & -1 & -1 & -1 & 1 \\
\hline 4 & -1 & -1 & 1 & 1 \\
\hline 16 & 1 & -1 & 1 & 1 \\
\hline 22 & 1 & 1 & 1 & 1 \\
\hline 13 & 1 & -1 & -1 & 1 \\
\hline 1 & -1 & \begin{tabular}{|c|}
-1 \\
\end{tabular} & -1 & 1 \\
\hline 19 & 1 & 1 & -1 & 1 \\
\hline 31 & -1 & 1 & -1 & 1 \\
\hline 7 & -1 & 1 & -1 & 1 \\
\hline 37 & 1 & -1 & -1 & 1 \\
\hline 18 & 1 & -1 & 1 & 3 \\
\hline 6 & -1 & -1 & 1 & 3 \\
\hline 21 & 1 & 1 & -1 & 3 \\
\hline 33 & -1 & 1 & -1 & 3 \\
\hline 30 & -1 & -1 & 1 & 3 \\
\hline 45 & 1 & 1 & -1 & 3 \\
\hline 42 & 1 & \begin{tabular}{|c|}
-1 \\
\end{tabular} & 1 & 3 \\
\hline 27 & -1 & -1 & -1 & 3 \\
\hline 39 & 1 & -1 & -1 & 3 \\
\hline 24 & 1 & 1 & 1 & 3 \\
\hline 3 & -1 & -1 & -1 & 3 \\
\hline 12 & -1 & 1 & 1 & 3 \\
\hline 15 & 1 & -1 & -1 & 3 \\
\hline 9 & \begin{tabular}{|l|}
-1 \\
\end{tabular} & 1 & -1 & 3 \\
\hline 36 & -1 & 1 & 1 & 3 \\
\hline 48 & 1 & 1 & 1 & 3 \\
\hline 26 & -1 & -1 & -1 & 2 \\
\hline 41 & 1 & \begin{tabular}{l|}
-1 \\
\end{tabular} & 1 & 2 \\
\hline 35 & -1 & 1 & 1 & 2 \\
\hline 29 & -1 & -1 & 1 & 2 \\
\hline 38 & 1 & -1 & -1 & 2 \\
\hline 11 & -1 & 1 & 1 & 2 \\
\hline 5 & -1 & -1 & 1 & 2 \\
\hline 20 & 1 & 1 & -1 & 2 \\
\hline 8 & -1 & 1 & -1 & 2 \\
\hline 2 & -1 & -1 & -1 & 2 \\
\hline 47 & 1 & 1 & 1 & 2 \\
\hline 14 & 1 & -1 & -1 & 2 \\
\hline 23 & 1 & 1 & 1 & 2 \\
\hline 17 & 1 & -1 & 1 & 2 \\
\hline 44 & 1 & 1 & -1 & 2 \\
\hline 32 & -1 & 1 & -1 & 2 \\
\hline
\end{tabular}

Factors code: Temperature $\left(80^{\circ} \mathrm{C}=-1,160^{\circ} \mathrm{C}=+1\right)$, Pressure $(250$ bar $=-1$, $350 \mathrm{bar}=+1), \mathrm{CO}_{2}$ flow rate $(1 \mathrm{ml} / \mathrm{min}=-1,4 \mathrm{ml} / \mathrm{min}=+1)$, Fluid type (Pure $\mathrm{SCCO}_{2}=1, \mathrm{SCCO}_{2}+5 \%(\mathrm{v} / \mathrm{v})$ toluene $=2, \mathrm{SC} \mathrm{CO}_{2}+5 \%(\mathrm{v} / \mathrm{v})$ heptane $=$ $3)$.

\section{Experimental Procedure}

Soil samples were spiked with $10 \mathrm{w} / \mathrm{w} \%$ crude oil and placed in the extraction chamber. The extraction chamber was kept in the oven at the desired temperature until thermal equilibrium was reached (30-60 $\mathrm{min}$ ). The chamber was then pressurized with $\mathrm{CO}_{2}$ to the desired pressure and kept for another 30 minutes to reach equilibrium. In the case of modified $\mathrm{CO}_{2}$, the second syringe pump was used to deliver the co-solvent (heptane or toluene), which was mixed with the $\mathrm{CO}_{2}$ stream at desired ratio. Pure and modified carbon dioxide at supercritical condition was then added to the ISCO SCF Extraction system (SFX system) and equilibrated for about 15 minutes. The temperature of the SFX system was maintained at the same temperature as the oven which had the extraction chamber that contained the sample. The SCF was allowed to flow through the coil of tubing and enter the extraction chamber from the bottom. The fluid was equilibrated with the spiked soil sample for at least 30 minutes. The supercritical solution was then allowed to flow into a vial and the extract was separated from the supercritical fluid by depressurizing the system in the cold trap. For the runs with pure $\mathrm{CO}_{2}$, mass of the extract collected in the vial was measured at different volumes of $\mathrm{CO}_{2}(15,25,35,50$, $100,150,200,300$ and $400 \mathrm{ml})$ passed through the sample. For the runs with modified $\mathrm{CO}_{2}$, mass of the extract collected in the vial was only measured at $400 \mathrm{ml}$ of the SCF passed through the sample. At the end of the experiment (after 400 $\mathrm{ml}$ of the fluid was passed through the sample), the extraction process was stopped and the pressure in the extraction chamber was slowly dropped to atmospheric pressure.

After extraction, the residual oil remaining in the soil sample was removed from the soil matrix by soxhlet extraction using dichloromethane. The original crude oil, the extract (collected from the SFE process), and the residual oil (collected from the soil samples) were analyzed by a gas chromatograph (Chrompack, CP9001) as previously explained [33]. Hydrocarbon profiles of the extracts and the residues were compared to that of the original crude. The residual hydrocarbons in the soil, after SFE process, were also analyzed for concentration of total petroleum hydrocarbon (TPH) and polycyclic aromatic hydrocarbons (PAHs). In addition, surface topography of the soil samples after SFE process was obtained by Scanning Electron Microscopy (JEOL 5600).

\section{E. Determination of Total Petroleum Hydrocarbon (TPH) in the Treated Soil}

About $5 \mathrm{~g}$ of the homogenized soil was placed in a $50 \mathrm{ml}$ beaker. The sample was acidified to $\mathrm{pH} 2$ with approximately $0.1 \mathrm{ml}$ of concentrated hydrochloric acid. Then $5 \mathrm{~g} \mathrm{MgSO}_{4}$ was added to the acidified sample and stirred to create a smooth paste. The paste was spread on the sides of the beaker and left for about 15-30 minutes at room temperature until the material was solidified. The solids were transferred to a mortar and grinded to a fine powder. The powder was then added to a paper extraction thimble. The thimble was placed in a soxhlet apparatus and extracted using n-haxane. After removing the solvent the amount of TPH was calculated from the weight of residue and the sample.

\section{F. Determination of Polycyclic Aromatic Hydrocarbon (PAHs) in the Treated Soil}

A total of 16 common PAHs were analyzed by extracting them from soil with hexane:acetone (50:50) using soxhlet extraction method. After carefully evaporating the solvent under nitrogen, a $20 \mu \mathrm{l}$ aliquot of the extract was injected into an HPLC (Waters 2695 Alliance Separation Module), Waters 474 Scanning Fluorescence Detector coupled with Waters 486 UV Detector and Waters Millennium 32 Chromatographic Manager workstation. The HPLC column 
used in this study was a chromosphere-3PAH column $(100 * 4.6 \mathrm{~mm}$ ID, $3 \mu \mathrm{m})$. The $16 \mathrm{PAH}$ compounds were detected by ultraviolet (UV) and fluorescence detectors simultaneously.

\section{RESULTS AND DiSCUSSIONS}

The $\mathrm{CO}_{2}$ extraction efficiency (the ratio of extracted hydrocarbons to the initial amount of crude oil in place) is used throughout this study to evaluate the capacity of $\mathrm{CO}_{2}$ to extract hydrocarbons from the soil. The average extraction efficiencies obtained at each of the investigated operating conditions are tabulated in Table II and shown in Fig. 2. Values of density, viscosity and kinematic viscosity of pure $\mathrm{CO}_{2}$ at the pressures and temperatures used in this study were also calculated using NIST Chemistry WebBook in order to investigate their influence on the SFE process. Although both density and viscosity of $\mathrm{CO}_{2}$ always increase with pressure and decrease with temperature, the combined property (kinematic viscosity) does not show a constant effect with pressure and temperature. The temperature and pressure combinations employed in this study were: 250 and 350 bar at 80 and $160{ }^{\circ} \mathrm{C}$. Bu Hasa crude oil, which was used in this study, contains significant amount of light hydrocarbons [33]. Therefore, n-heptane and toluene were chosen as chemical modifiers for the $\mathrm{SC} \mathrm{CO}_{2}$ to investigate the effect of a polar and a non-polar modifier with the same carbon number. n-heptane, a non-polar aliphatic hydrocarbon, and toluene, an aromatic hydrocarbon with a polarity index of 2.4 , have high solvency for hydrocarbons.

The lowest value of extraction efficiency $(68.38 \% \pm 1.99)$ was obtained for modified $\mathrm{SC} \mathrm{CO}_{2}$ (with an addition of $5 \%$ toluene) at $250 \mathrm{bar}, 160{ }^{\circ} \mathrm{C}$ and $\mathrm{CO}_{2}$ flow rate of $4 \mathrm{ml} / \mathrm{min}$, while the maximum efficiency $(92.26 \% \pm 5.40)$ was found for $\mathrm{SC} \mathrm{CO}_{2}$ (with an addition of $5 \%$ n-heptane) at $350 \mathrm{bar}$, $80{ }^{\circ} \mathrm{C}$ and $\mathrm{CO}_{2}$ flow rate of $1 \mathrm{ml} / \mathrm{min}$. The highest efficiency obtained by $\mathrm{SC} \mathrm{CO}_{2}$ alone (without modifier) was $78.51 \%$ \pm 0.46 , which was obtained at 350 bar, $160{ }^{\circ} \mathrm{C}$ and $\mathrm{CO}_{2}$ flow rate of $1 \mathrm{ml} / \mathrm{min}$. The complexity of crude oil mixture containing many compounds with significantly different physico-chemical properties that vary with temperature and pressure are believed to cause such a large variation in the extraction capacity of $\mathrm{SC} \mathrm{CO}_{2}$.

TABLE II: PROPERTIES AND AVERAGE EXTRACTION EFFICIENCIES OF SUPERCRITICAL FLUIDS FOR SOIL SAMPLES CONTAMINATED WITH CRUDE OIL

\begin{tabular}{|c|c|c|c|c|c|c|c|}
\hline Temperature $\left({ }^{\circ} \mathrm{C}\right)$ & Pressure (bar) & $\begin{array}{l}\mathrm{CO}_{2} \text { flow rate } \\
(\mathrm{ml} / \mathrm{min})\end{array}$ & $\begin{array}{l}\text { Modifier 5\% } \\
(\mathrm{v} / \mathrm{v})\end{array}$ & $\begin{array}{l}\text { CO2 density } \\
(\mathrm{g} / \mathrm{ml})\end{array}$ & $\begin{array}{l}\text { CO2 viscosity } \\
(\mu \mathrm{Pa} \cdot \mathrm{s})\end{array}$ & $\begin{array}{c}\text { CO2 kinematic } \\
\text { viscosity } \times 108 \\
(\mathrm{~m} 2 / \mathrm{s})\end{array}$ & $\begin{array}{c}\text { Average extraction } \\
\text { efficiency }(\%) \pm \\
\text { SEM }^{*}\end{array}$ \\
\hline 80 & 250 & 1 & - & 0.68622 & 56.03 & 8.17 & $72.32 \pm 0.49$ \\
\hline 80 & 250 & 4 & - & 0.68622 & 56.03 & 8.17 & $75.07 \pm 0.92$ \\
\hline 80 & 350 & 1 & - & 0.78897 & 70.376 & 8.92 & $77.76 \pm 0.78$ \\
\hline 80 & 350 & 4 & - & 0.78897 & 70.376 & 8.92 & $77.40 \pm 0.55$ \\
\hline 160 & 250 & 1 & - & 0.39294 & 33.905 & 8.63 & $68.44 \pm 0.43$ \\
\hline 160 & 250 & 4 & - & 0.39294 & 33.905 & 8.63 & $69.03 \pm 1.47$ \\
\hline 160 & 350 & 1 & - & 0.52948 & 43.726 & 8.26 & $78.51 \pm 0.46$ \\
\hline 160 & 350 & 4 & - & 0.52948 & 43.726 & 8.26 & $77.91 \pm 0.37$ \\
\hline 80 & 250 & 1 & n-Heptane & - & - & - & $80.40 \pm 2.96$ \\
\hline 80 & 250 & 4 & n-Heptane & - & - & - & $79.51 \pm 2.99$ \\
\hline 80 & 350 & 1 & n-Heptane & - & - & - & $92.26 \pm 5.40$ \\
\hline 80 & 350 & 4 & n-Heptane & - & - & - & $87.68 \pm 1.20$ \\
\hline 160 & 250 & 1 & n-Heptane & - & - & - & $73.03 \pm 2.18$ \\
\hline 160 & 250 & 4 & n-Heptane & - & - & - & $78.23 \pm 4.66$ \\
\hline 160 & 350 & 1 & n-Heptane & - & - & - & $85.07 \pm 0.55$ \\
\hline 160 & 350 & 4 & n-Heptane & - & - & - & $82.91 \pm 5.02$ \\
\hline 80 & 250 & 1 & Toluene & - & - & - & $76.05 \pm 2.58$ \\
\hline 80 & 250 & 4 & Toluene & - & - & - & $71.65 \pm 1.43$ \\
\hline 80 & 350 & 1 & Toluene & - & - & - & $77.63 \pm 3.30$ \\
\hline 80 & 350 & 4 & Toluene & - & - & - & $81.01 \pm 0.56$ \\
\hline 160 & 250 & 1 & Toluene & - & - & - & $72.35 \pm 3.02$ \\
\hline 160 & 250 & 4 & Toluene & - & - & - & $68.38 \pm 1.99$ \\
\hline 160 & 350 & 1 & Toluene & - & - & - & $70.38 \pm 0.15$ \\
\hline 160 & 350 & 4 & Toluene & - & - & - & $70.13 \pm 2.38$ \\
\hline
\end{tabular}

*SEM: Standard Error of the Mean

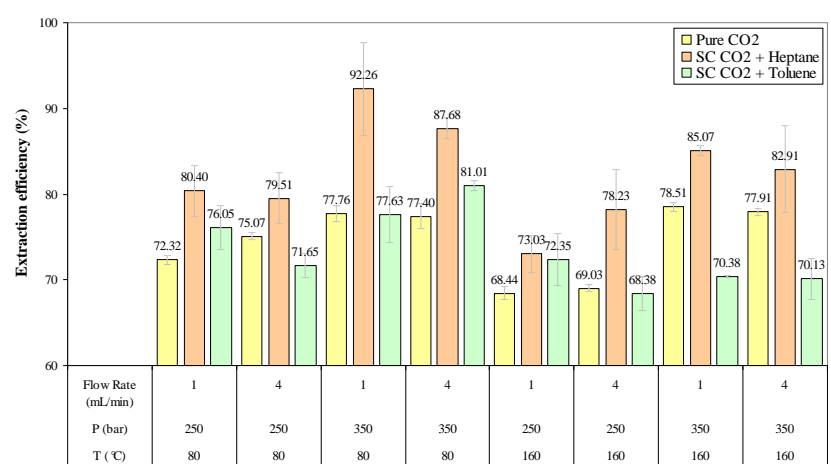

Fig. 2. Average extraction efficiency for all runs.
Results of the multi-way ANOVA based on the original values of extraction efficiency show that temperature, pressure and fluid type have significant effect on the extraction efficiency, but the flow rate of the $\mathrm{CO}_{2}$ does not have a significant effect, i.e. Sig. $>0.05$ (Table III). Moreover, pressure and fluid type interact. This means that the effect of pressure depends on which fluid is used and vice versa, which is not the case with temperature. However, by checking the validity of the ANOVA model using residual analysis, the normality assumption was found to be satisfied, i.e. the p-value was higher than $5 \%$. But, the homogeneity of variance assumption was found to be satisfied with respect to 
the factors flow rate, temperature and pressure, but it was not satisfied with respect to fluid type. This violation of the assumptions of ANOVA should not have adverse effects on the validity of the method because when the model is balanced (i.e., there are equal numbers of replications per cell) ANOVA is robust to such a violation [36].

TABLE III: STATISTICAL ANALYSIS BASED ON A MULTI-WAY ANOVA

\begin{tabular}{|c|c|c|c|c|c|}
\hline Source & $\begin{array}{c}\text { Type III Sum of } \\
\text { Squares }\end{array}$ & df* & Mean Square & $\mathbf{F} * *$ & Sig. \\
\hline Corrected Model & $1760.595^{(a)}$ & 23 & 76.548 & 6.394 & 0.000 \\
\hline Intercept & $283,086.096$ & 1 & $283,086.096$ & $23,646.971$ & 0.000 \\
\hline Temperature & 246.404 & 1 & 246.404 & 20.583 & 0.000 \\
\hline Pressure & 458.761 & 1 & 458.761 & 38.322 & 0.000 \\
\hline Fluid Type & 759.580 & 2 & 379.790 & 31.725 & 0.000 \\
\hline Flow Rate & 2.316 & 1 & 2.316 & 0.193 & 0.664 \\
\hline Temperature*Pressure & 0.906 & 1 & 0.906 & 0.076 & 0.786 \\
\hline Temperature*Fluid Type & 36.043 & 2 & 18.021 & 1.505 & 0.242 \\
\hline Pressure*Fluid Type & 86.269 & 2 & 43.134 & 3.603 & 0.043 \\
\hline Temperature*Pressure*Fluid Type & 64.238 & 2 & 32.119 & 2.683 & 0.089 \\
\hline Temperature*Flow Rate & 0.718 & 1 & 0.718 & 0.060 & 0.809 \\
\hline Pressure*Flow Rate & 1.245 & 1 & 1.245 & 0.104 & 0.750 \\
\hline Temperature*Pressure*Flow Rate & 2.800 & 1 & 2.800 & 0.234 & 0.633 \\
\hline Fluid Type*Flow Rate & 7.423 & 2 & 3.712 & 0.310 & 0.736 \\
\hline Temperature*Fluid Type*Flow Rate & 21.330 & 2 & 10.665 & 0.891 & 0.423 \\
\hline Pressure*Fluid Type*Flow Rate & 66.958 & 2 & 33.479 & 2.797 & 0.081 \\
\hline Temperature*Pressure*Fluid Type*Flow Rate & 5.604 & 2 & 2.802 & 0.234 & 0.793 \\
\hline Error & 287.312 & 24 & 11.971 & & \\
\hline Total & $285,134.003$ & 48 & & & \\
\hline Corrected Total & $2,047.907$ & 47 & & & \\
\hline
\end{tabular}

(a) R Squared $=0.860$ (Adjusted R Squared $=0.725$ )

$*$ df: degrees of freedom.

** F: Test Statistics.

\section{A. Effect of Temperature}

Fig. 3 illustrates the effect of temperature on the extraction efficiency. Values on the figure (including bars showing the standard error of the mean) represent the mean value of extraction efficiency for 24 experiments at each temperature. Results indicate that temperature has an inverse effect on the extraction efficiency. This might be due to the increase in the kinematic viscosity and interfacial tension due to the decrease in $\mathrm{CO}_{2}$ density with an increase in temperature.

\section{B. Effect of Flow Rate}

Effect of flow rate (1 and $4 \mathrm{ml} / \mathrm{min}$ ) on the extraction efficiency is shown on Fig. 4. Values on the figure represent the mean value of the extraction efficiency for 24 experiments at each flow rate. Decreasing the flow rate usually ensures more contact time and results in higher extraction efficiencies for a given amount of $\mathrm{CO}_{2}$ used. However, saturation is achieved at certain flow rates, below which the flow rate does not affect the extraction efficiency of the solvent. Results indicate that flow rate does not affect the extraction efficiency for the conditions used in this study. Therefore, the extraction process should be operated at 4 $\mathrm{ml} / \mathrm{min}$ in order to reduce the extraction time.

\section{Effect of Pressure and Fluid Type}

Due to the interaction between pressure and fluid type, effect of these parameters cannot be shown separately, therefore, Fig. 5 shows the effect of both pressure and the fluid type on the extraction efficiency. Each point on Fig. 5 represents the mean value of extraction efficiency for 8 experiments for each fluid type at a given pressure. As shown in the figure, the extraction efficiency of pure and modified $\mathrm{SC} \mathrm{CO}_{2}$ increases as the pressure is increased. This might be due to the decrease in the kinematic viscosity due to the increase in $\mathrm{CO}_{2}$ density with an increase in pressure. Moreover, the extraction efficiency of the modified $\mathrm{SC} \mathrm{CO}_{2}$ by $5 \%(\mathrm{v} / \mathrm{v})$ heptane is higher than that of both pure $\mathrm{SC} \mathrm{CO}_{2}$ and modified $\mathrm{SC} \mathrm{CO}_{2}$ with $5 \%(\mathrm{v} / \mathrm{v})$ toluene. The higher extraction efficiency when utilizing heptane can probably be attributed to the richness of $\mathrm{Bu}$ Hasa crude oil in aliphatic non-polar hydrocarbon compounds such as n-alkanes $\left(\mathrm{C}_{6}-\mathrm{C}_{22}\right)$ as reported in 2007 by Al-Marzouqi et al. [33]. However, due to the interaction between pressure and fluid type, the extraction efficiency of modified $\mathrm{SC} \mathrm{CO}_{2}$ with $5 \%(\mathrm{v} / \mathrm{v})$ toluene is found to be higher than that for pure $\mathrm{SC} \mathrm{CO}_{2}$ at the low pressure ( 250 bar) but lower at the high pressure $(350$ bar).

\section{Compositional analysis of extracts and residues}

Gas chromatograms of the original crude, extracted oil obtained from the SFE process, and the residual oil remaining in the soil samples are shown in Fig. 6 for a representative run. As shown in the figure, a modified $\mathrm{CO}_{2}$ with $5 \%$ heptane at 350 bar, $80{ }^{\circ} \mathrm{C}$ and $\mathrm{CO}_{2}$ flow rate of $1 \mathrm{ml} / \mathrm{min}$ is capable of extracting gasoline and diesel range hydrocarbons (up to $\mathrm{C}_{22}$ ). Only a very small amount of hydrocarbons remained in the soil sample as residue, suggesting that chemically modified $\mathrm{CO}_{2}$ (with 5\% heptane) at this pressure and temperature can extract a wide range of hydrocarbons, in agreement with the results of extraction efficiency (Table II). Similar results were obtained for the pure and modified $\mathrm{CO}_{2}$ with $5 \%$ toluene at the same conditions $\left(350\right.$ bar and $\left.80{ }^{\circ} \mathrm{C}\right)$. The residual oil remaining in the soil sample was not significantly different in the case of chemically modified $\mathrm{CO}_{2}$ as compared with extraction by pure $\mathrm{CO}_{2}$ at the same conditions. This might be due to the high density of $\mathrm{SC} \mathrm{CO}_{2}$ at the studied pressures (250 and 350 bar). Therefore, the enhancement in the solvating power of $\mathrm{SC} \mathrm{CO}_{2}$ by the addition of $5 \%$ 
heptane or toluene was not very significant at these high pressures.

\section{E. Scanning Electron Microcopy (SEM)}

Scanning electron micrographs of selected soil samples are shown on Fig. 7. The results obtained from these images are in agreement with the results obtained for extraction efficiency. The SEM image of the untreated soil contaminated with $\mathrm{Bu}$ Hasa crude oil (a) and treated sample with pure $\mathrm{SC} \mathrm{CO}_{2}$ at 250 bar and $160{ }^{\circ} \mathrm{C}$ (b) showed some remaining hydrocarbons. Therefore, pure $\mathrm{SC} \mathrm{CO}_{2}$ at the low pressure and high temperature was not able to completely remediate the contaminated soil. However, pure and modified $\mathrm{SC} \mathrm{CO}_{2}$, at high pressure and low temperature, were able to effectively remove the crude oil from the contaminated soil, which is in agreement with the previous observations obtained by the GC analysis of the extracts and residues and with the results in Table II.

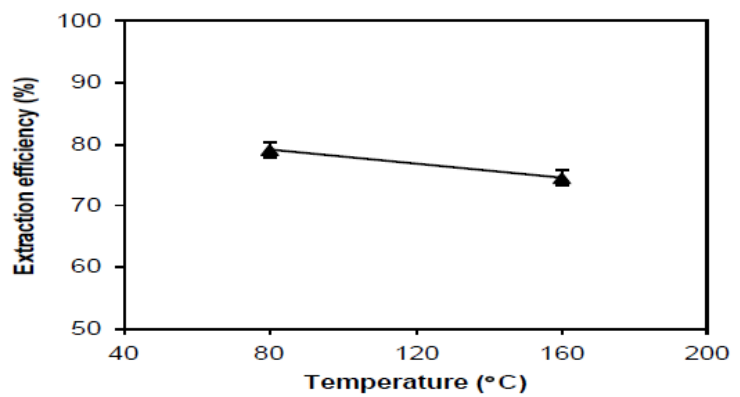

Fig. 3. Effect of temperature on the extraction efficiency.

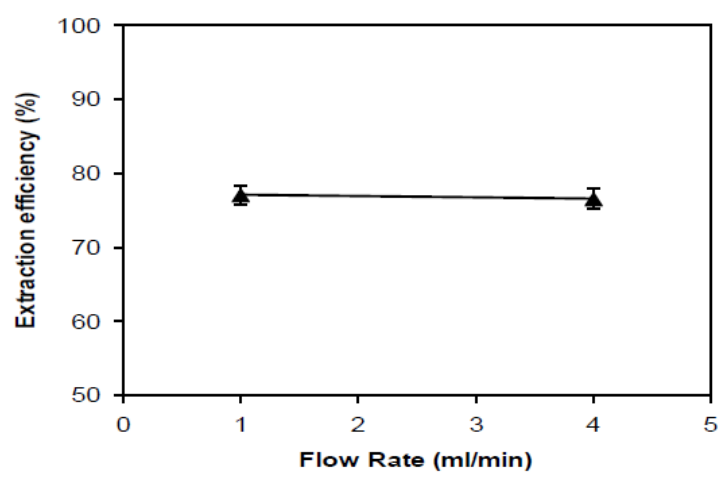

Fig. 4. Effect of $\mathrm{CO}_{2}$ flow rate on the extraction efficiency.

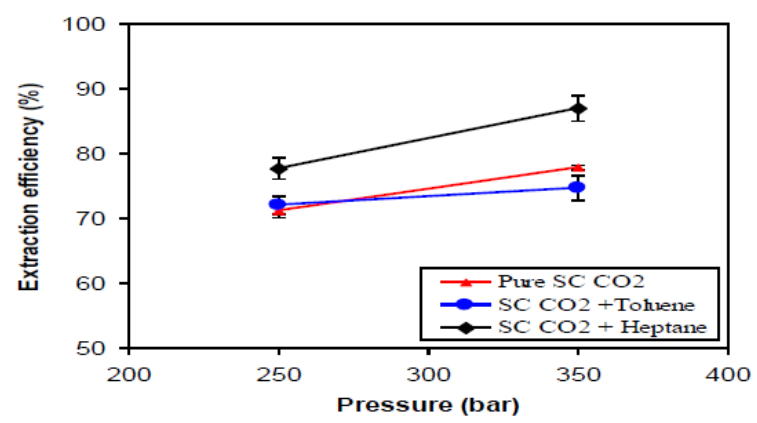

Fig. 5. Effect of pressure and fluid type on the extraction efficiency.

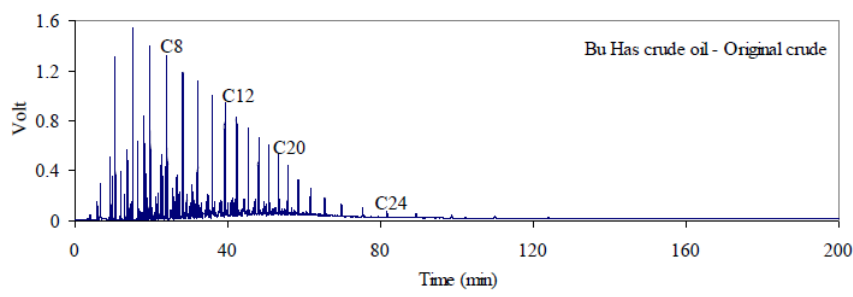

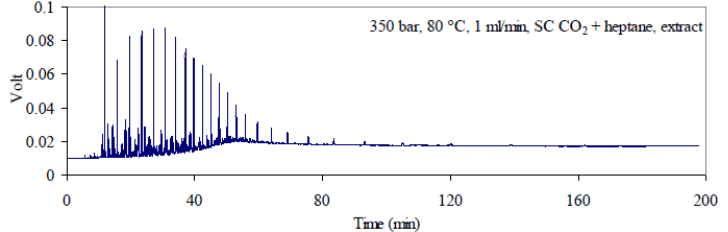

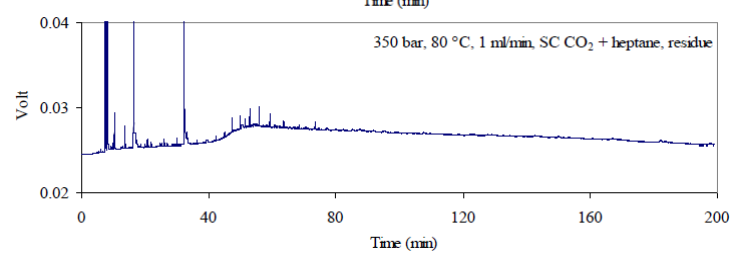

Fig. 6. Gas chromatograms of the original Bu Hasa crude oil, extract obtained from SFE, and the residue. SFE conditions: $350 \mathrm{bar}, 80^{\circ} \mathrm{C}, 1 \mathrm{ml} / \mathrm{min}$, SC $\mathrm{CO}_{2}+5 \%(\mathrm{v} / \mathrm{v})$ heptane.

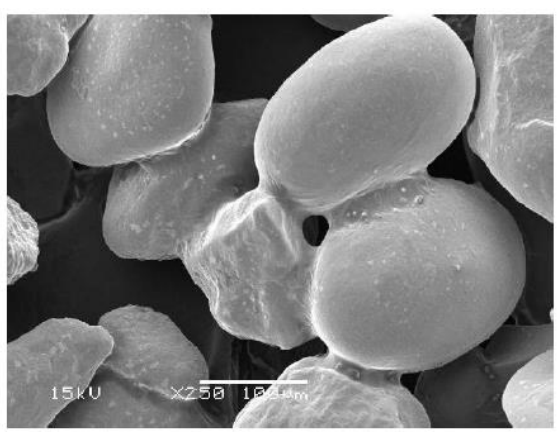

a)

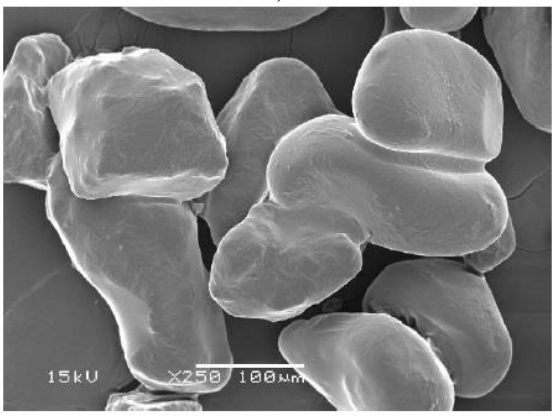

b)

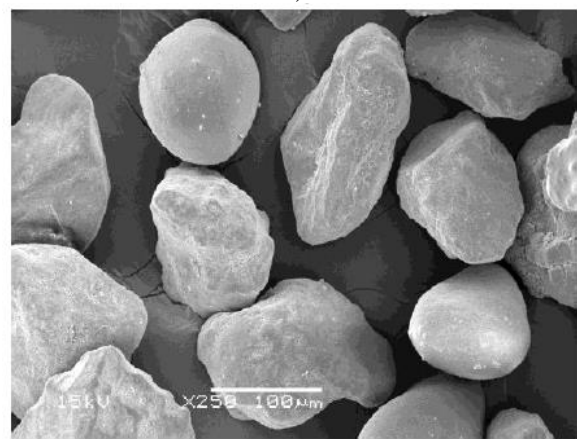

c)

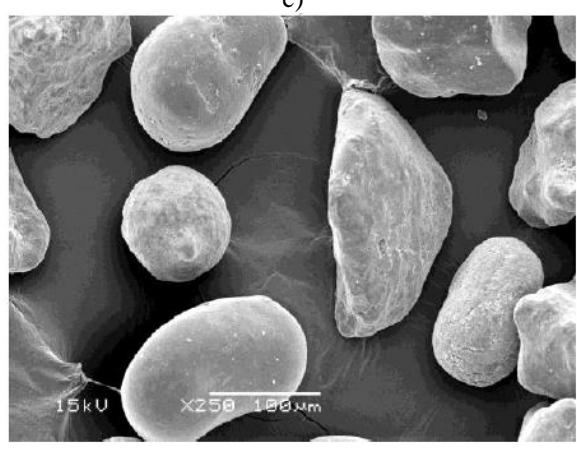

d)

Fig. 7. Contaminated soil with Bu Hasa crude oil (a) and soil after extraction by: pure $\mathrm{SC} \mathrm{CO}_{2}$ at $250 \mathrm{bar}, 160{ }^{\circ} \mathrm{C}(\mathrm{b})$, pure $\mathrm{SC} \mathrm{CO}_{2}$ at $350 \mathrm{bar}, 80^{\circ} \mathrm{C}(\mathrm{c}), \mathrm{SC}$ $\mathrm{CO}_{2}+5 \%(\mathrm{v} / \mathrm{v})$ heptane at $350 \mathrm{bar}, 80{ }^{\circ} \mathrm{C}(\mathrm{d})$. 


\section{F. Analysis of Total Petroleum Hydrocarbon}

TABLE IV: TPH ANALYSIS OF THE CLEAN SOIL, SOIL SPIKED WITH CRUDE OIL BEFORE SFE AND TREATED SOIL AFTER THE SFE PROCESS

\begin{tabular}{|c|c|c|c|c|c|}
\hline Sample & $\begin{array}{c}\text { SFE } \\
\mathbf{T} \\
\left({ }^{\circ} \mathbf{C}\right)\end{array}$ & $\begin{array}{c}\text { SFE } \\
\mathbf{P} \\
(\mathbf{b a r})\end{array}$ & $\begin{array}{c}\text { TPH } \\
(\boldsymbol{\mu g} / \mathbf{m g})\end{array}$ & $\begin{array}{c}\text { TPH } \\
\text { Removal } \\
(\%)\end{array}$ & $\begin{array}{c}\text { Extraction } \\
\text { Efficiency } \\
(\boldsymbol{\%})\end{array}$ \\
\hline Clean soil & - & - & $<0.23$ & - & - \\
\hline $\begin{array}{c}\text { Spiked soil with } \\
\text { crude oil before } \\
\text { SFE }\end{array}$ & - & - & 56875 & - & - \\
\hline \multirow{4}{*}{$\begin{array}{c}\text { Treated soil after } \\
\text { SFE }\end{array}$} & 160 & 250 & 13564 & 76.15 & 69.22 \\
\cline { 2 - 6 } & 160 & 350 & 5129 & 90.98 & 77.95 \\
\cline { 2 - 6 } & 80 & 250 & 9361 & 83.54 & 71.83 \\
\hline
\end{tabular}

The capacity of pure $\mathrm{SC} \mathrm{CO}_{2}$ to extract $\mathrm{TPH}$ from soil saturated with $\mathrm{Bu}$ Hasa crude oil was investigated for some selected runs (Table IV). As shown in the table, pure $\mathrm{SC} \mathrm{CO}_{2}$ at high pressure (350 bar) and low temperature $\left(80{ }^{\circ} \mathrm{C}\right)$, is capable of extracting $92.86 \%$ of TPH from the polluted soil compared to $90.98 \%$ removal of TPH at the same pressure and higher temperature $\left(160{ }^{\circ} \mathrm{C}\right)$. Removal percentage was less at the lower pressure of 250 bar $(83.54 \%$ and $76.15 \%$ at 80 and $160{ }^{\circ} \mathrm{C}$, respectively), which matches the results obtained from the extraction efficiency of $\mathrm{SC} \mathrm{CO}_{2}$. This study shows that pure $\mathrm{SC} \mathrm{CO}_{2}$ can effectively remediate the contaminated soil and thus reduce the harmful effects of the TPH compounds on the environment.

The PAHs measurement was conducted for selected runs to investigate the efficiency of $\mathrm{SC} \mathrm{CO}_{2}$ in extracting PAHs from soil samples contaminated with $\mathrm{Bu}$ Hasa crude oil. Concentration of 16 PAHs in the selected soil samples after the SFE process is tabulated in Table V. Results show that the modified $\mathrm{SC} \mathrm{CO}_{2}$ with $5 \%(\mathrm{v} / \mathrm{v})$ heptane at low temperature $\left(80{ }^{\circ} \mathrm{C}\right)$ and high pressure $(350$ bar) was not able to completely remove naphthalene, acenaphthene, anthracene, fluoranthene and chrycene from the contaminated soil. Also, the extraction by pure $\mathrm{SC} \mathrm{CO}_{2}$ at the same pressure and temperature was the worst among all other conditions to extract the fluoranthene, pyrene, benzo (b) flouranthene, benzo $(\mathrm{g}, \mathrm{h}, \mathrm{i})$ perylene and indeno (1,2,3-cd) pyrene. However, pure $\mathrm{SC} \mathrm{CO}_{2}$ at $160{ }^{\circ} \mathrm{C}$ and 350 bar resulted in a better extraction of the 16 PAHs. This might be attributed to the effect of high temperature, which increases the volatility of the PAHs and thus increases their solubility in the fluid. Further studies are needed to confirm this result.

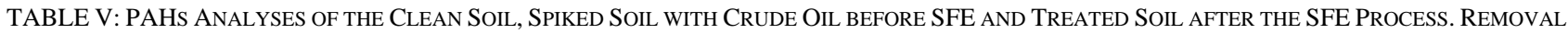
EFFICIENCIES (\%) ARE SHOWN IN PARENTHESIS. REMOVAL EFFICIENCY WAS ASSUMED 100\% FOR PAH CONCENTRATION < LOD*

\begin{tabular}{|c|c|c|c|c|c|c|c|c|}
\hline & Sample & $\begin{array}{c}\text { Clean } \\
\text { soil }\end{array}$ & $\begin{array}{l}\text { Spiked soil } \\
\text { with crude } \\
\text { oil before }\end{array}$ & \multicolumn{5}{|c|}{ Treated soil after SFE } \\
\hline & Temperature $\left({ }^{\circ} \mathrm{C}\right)$ & - & - & 80 & 160 & 160 & 80 & 80 \\
\hline & Pressure (bar) & - & - & 350 & 250 & 350 & 250 & 350 \\
\hline & Modifier & - & - & - & - & - & - & Heptane \\
\hline \multirow{16}{*}{ 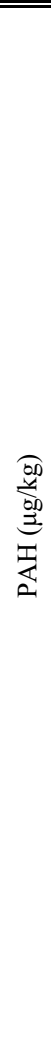 } & Naphthalene & $<7.89$ & 10648 & $\begin{array}{c}<7.89 \\
(\mathbf{1 0 0 \%}) \\
\end{array}$ & $<7.89(\mathbf{1 0 0 \%})$ & $\begin{array}{c}<7.89 \\
(\mathbf{1 0 0 \%}) \\
\end{array}$ & $\begin{array}{c}<7.89 \\
(\mathbf{1 0 0 \%}) \\
\end{array}$ & $\begin{array}{c}78 \\
(\mathbf{9 9 . 2 6 \% )} \\
\end{array}$ \\
\hline & Acenaphthylene & $<10.7$ & $<10.7$ & $<10.7$ & $<10.7$ & $<10.7$ & $<10.7$ & $<10.7$ \\
\hline & Acenaphthene & $<5.12$ & 3260 & $\begin{array}{c}7.89 \\
(99.75 \%)\end{array}$ & $16.8(\mathbf{9 9 . 4 8 \% )}$ & $\begin{array}{c}15.4 \\
(\mathbf{9 9 . 5 2 \% )}\end{array}$ & $16(\mathbf{9 9 . 5 0 \% )}$ & $\begin{array}{c}19.5 \\
(\mathbf{9 9 . 4 0 \% )}\end{array}$ \\
\hline & Flourene & $<5.53$ & 357 & $\begin{array}{c}<5.53 \\
(\mathbf{1 0 0 \%}) \\
\end{array}$ & $<5.53(\mathbf{1 0 0 \%})$ & $\begin{array}{c}<5.53 \\
(\mathbf{1 0 0 \%}) \\
\end{array}$ & $\begin{array}{c}<5.53 \\
(\mathbf{1 0 0 \%})\end{array}$ & $\begin{array}{c}<5.53 \\
(\mathbf{1 0 0 \%})\end{array}$ \\
\hline & Phenanthrene & $<4.85$ & 10417 & $\begin{array}{c}279 \\
(\mathbf{9 7 . 3 2 \%}) \\
\end{array}$ & $66.8(99.35 \%)$ & $\begin{array}{c}75.1 \\
(\mathbf{9 9 . 2 7 \%}) \\
\end{array}$ & $\begin{array}{c}553 \\
(\mathbf{9 4 . 6 9 \%}) \\
\end{array}$ & $\begin{array}{c}292 \\
(\mathbf{9 7 . 1 9 \%}) \\
\end{array}$ \\
\hline & Anthracene & $<4.99$ & $<4.99$ & $<4.99$ & $<4.99$ & $<4.99$ & $<4.99$ & $<4.99$ \\
\hline & Fluoranthene & $<4.98$ & 947 & $\begin{array}{c}42.3 \\
(\mathbf{9 5 . 5 3 \% )}\end{array}$ & $32.3(\mathbf{9 6 . 5 8 \%})$ & $\begin{array}{c}<4.98 \\
(\mathbf{1 0 0 \%})\end{array}$ & $\begin{array}{c}8.19 \\
(\mathbf{9 9 . 1 3 \% )}\end{array}$ & $\begin{array}{c}40.2 \\
(\mathbf{9 5 . 7 5 \%})\end{array}$ \\
\hline & Pyrene & $<5.00$ & 3921 & $\begin{array}{c}924 \\
(\mathbf{7 6 . 4 3 \%})\end{array}$ & $274(\mathbf{9 3 . 0 1 \% )}$ & $\begin{array}{c}63.1 \\
(\mathbf{9 8 . 3 9 \%})\end{array}$ & $\begin{array}{c}393 \\
(\mathbf{8 9 . 9 7 \% )} \\
\end{array}$ & $\begin{array}{c}622 \\
(\mathbf{8 4 . 1 3 \%})\end{array}$ \\
\hline & Benzo(a)anthracene & $<4.90$ & 1168 & $\begin{array}{c}<4.90 \\
(\mathbf{1 0 0 \%})\end{array}$ & $9.53(\mathbf{9 9 . 1 8 \% )}$ & $\begin{array}{c}11.4 \\
(\mathbf{9 9 . 0 2 \%})\end{array}$ & $\begin{array}{c}<4.90 \\
(\mathbf{1 0 0 \%})\end{array}$ & $\begin{array}{c}9.85 \\
(\mathbf{9 9 . 1 5 \%})\end{array}$ \\
\hline & Chrycene & $<4.92$ & 1107 & $\begin{array}{c}9.85 \\
(\mathbf{9 9 . 1 1 \% )} \\
\end{array}$ & $<4.92(\mathbf{1 0 0 \%})$ & $\begin{array}{c}10.3 \\
(\mathbf{9 9 . 0 6 \% )} \\
\end{array}$ & $\begin{array}{c}<4.92 \\
(\mathbf{1 0 0 \%}) \\
\end{array}$ & $\begin{array}{c}10.8 \\
(\mathbf{9 9 . 0 2 \%})\end{array}$ \\
\hline & Benzo(b)flouranthene & $<4.54$ & $<4.54$ & $<4.54$ & $<4.54$ & $<4.54$ & $<4.54$ & $<4.54$ \\
\hline & Benzo(k)flouranthene & $<4.61$ & $<4.61$ & $<4.61$ & $<4.61$ & $<4.61$ & $<4.61$ & $<4.61$ \\
\hline & Benzo(a)pyrene & $<4.99$ & $<4.99$ & $<4.99$ & $<4.99$ & $<4.99$ & $<4.99$ & $<4.99$ \\
\hline & Dibenzo(a,h)anthracene & $<5.34$ & 283 & $\begin{array}{c}<5.34 \\
(\mathbf{1 0 0 \%})\end{array}$ & $<5.34(\mathbf{1 0 0 \%})$ & $\begin{array}{c}<5.34 \\
(\mathbf{1 0 0 \%})\end{array}$ & $\begin{array}{c}<5.34 \\
(\mathbf{1 0 0 \%})\end{array}$ & $\begin{array}{c}<5.34 \\
(\mathbf{1 0 0 \%})\end{array}$ \\
\hline & Benzo(g,h,i)perylene & $<5.45$ & 750 & $\begin{array}{c}37 \\
(\mathbf{9 5 . 0 6 \%}) \\
\end{array}$ & $<5.45(\mathbf{1 0 0 \%})$ & $\begin{array}{c}<5.45 \\
(\mathbf{1 0 0 \%})\end{array}$ & $\begin{array}{c}<5.45 \\
(\mathbf{1 0 0 \%})\end{array}$ & $\begin{array}{c}13.8 \\
(\mathbf{9 8 . 1 6 \% )}\end{array}$ \\
\hline & Indeno(1,2,3-cd)pyrene & $<5.42$ & 326 & $\begin{array}{c}36.2 \\
(\mathbf{8 8 . 8 9 \%})\end{array}$ & $<5.42(\mathbf{1 0 0 \%})$ & $\begin{array}{c}<5.42 \\
(\mathbf{1 0 0 \%})\end{array}$ & $\begin{array}{c}<5.42 \\
(\mathbf{1 0 0 \%})\end{array}$ & $\begin{array}{c}<5.42 \\
(\mathbf{1 0 0 \%})\end{array}$ \\
\hline \multicolumn{2}{|c|}{ "Extraction efficiency (\%) } & - & - & 78.69 & 69.22 & 77.95 & 71.83 & 97.66 \\
\hline
\end{tabular}

* LOD: limit of detection. 


\section{CONCLUSIONS}

Effects of temperature, pressure, $\mathrm{CO}_{2}$ flow rate and two modifiers (heptanes and toluene) at $5 \%(\mathrm{v} / \mathrm{v})$ on the extraction capacity of $\mathrm{SC} \mathrm{CO}_{2}$ were investigated. The results of this study indicate that $\mathrm{SC} \mathrm{CO}_{2}$ is an effective solvent, which leads to high extraction efficiencies when applied at high pressures. Furthermore, the results from this study show that the flow rate does not have a significant effect on the efficiency of $\mathrm{SC} \mathrm{CO}_{2}$. Therefore, it is recommended to use the high flow rate, i.e. $4 \mathrm{ml} / \mathrm{min}$, in order to reduce the time required for the remediation of contaminated soil. Moreover, the temperature, i.e. 80 and $160^{\circ} \mathrm{C}$, has no significant effect on the extraction efficiency of $\mathrm{SC} \mathrm{CO}_{2}$ at the high pressure (350 bar). Therefore, it is recommended to apply the low temperature during the extraction process in order to save energy. Chemical modification of $\mathrm{CO}_{2}$ by adding $5 \%$ heptane was more effective than the same level of modification by toluene. The optimum condition to extract hydrocarbons from soil contaminated with $\mathrm{Bu}$ Hasa crude oil was by modified $\mathrm{SC} \mathrm{CO}_{2}$ with $5 \%$ heptane at high pressure (350 bar), low temperature $\left(80{ }^{\circ} \mathrm{C}\right)$, and flow rate of $1 \mathrm{ml} / \mathrm{min}$. Supercritical $\mathrm{CO}_{2}$ was able to remove $92.86 \%$ of the TPH present in contaminated soil. Additionally, pure $\mathrm{SC} \mathrm{CO}_{2}$ and $\mathrm{SC} \mathrm{CO}_{2}$ chemically modified with $5 \%(\mathrm{v} / \mathrm{v})$ heptane were capable of significantly reducing the concentration levels of PAHs in the soil contaminated by Bu Hasa crude oil.

\section{CONFLICT OF INTEREST}

The authors declare no conflict of interest.

\section{AUTHOR CONTRIBUTIONS}

Abdulrazag Y. Zekri and Ali H. Al-Marzouqi; Designed the study and analyzed the data. Adel A. Azzam; assembled the extraction system and conducted the experimental work. Abdulrahman Y. Alraeesi; aided in interpreting the results and worked on the manuscript. All authors had approved the final version.

\section{ACKNOWLEDGEMENT}

The authors would like to thank Abu Dhabi National Oil Company (ADNOC), UAE, for providing the real samples to complete this study.

\section{REFERENCES}

[1] G. Anitescu and L. L. Tavlarides, "Supercritical extraction of contaminants from soils and sediments," The Journal of Supercritical Fluids, vol. 38, no. 2, pp. 167-180, 2006.

[2] E. Zhou and R. Crawford, "Effects of oxygen, nitrogen, and temperature on gasoline biodegradation in soil," Biodegradation, vol. 6 , pp. 127-140, 1995.

[3] E. W. Liebeg and T. J. Cutright, "The investigation of enhanced bioremediation through the addition of macro and micronutrients in a PAH contaminated soil," International Biodeterioration and Biodegradation, vol. 44, pp. 55-64, 1999.

[4] D. Sarkar et al., "Bioremediation of petroleum hydrocarbons in contaminated soils: comparison of biosolids addition, carbon supplementation, and monitored natural attenuation," Environmental Pollution, vol. 136, no. 1, pp. 187-195, 2005.

[5] N. Vasudevan and P. Rajaram, "Bioremediation of oil sludge contaminated soil," Environment International, vol. 26, no. 5-6, pp. 409-411, 2001.
[6] P. Okerentugba et al., "Spent mushroom compost for bioremediation of petroleum hydrocarbon polluted soil: A review," J Environ Sci Toxicol, vol. 4, no. 1, pp. 001-7, 2015.

[7] S. Paria, "Surfactant-enhanced remediation of organic contaminated soil and water," Advances in Colloid and Interface Science, vol. 138, pp. 24-58, 2008.

[8] M. W. Lim et al., "A comprehensive guide of remediation technologies for oil contaminated soil — Present works and future directions," Mar. Pollut.Bull., vol. 109, pp. 14-45, 2016.

[9] G. H. Hadian et al., "Bioremediation of soil contaminated crude oil by Agaricomycetes," J Environ Health Sci Eng., 2017, vol. 15, p. 8.

[10] H. Saad and E. Gulari, "Diffusion of carbon dioxide in heptane," $J$. Phys. Chem., vol. 88, pp. 136-139, 1984.

[11] D. J. Dixon and K. P. Johnston, "Supercritical fluids," Encyclopedia of Separation Technology, John Wiley and Sons, NY, USA, 1997, pp. 1544-1569.

[12] P. K. Wong and J. Wang, "The accumulation of polycyclic aromatic hydrocarbons in lubricating oil over time - A comparison of supercritical fluid and liquid-liquid extraction methods," Environmental Pollution vol. 112, pp. 407-415, 2001.

[13] A. S. Pimenta et al., "Characterisation of polycilic aromatic hydrocarbons in liquid products from pyrolysis of Eucalyptus grandis by supercritical fluid extraction and GC/MS determination," Fuel, vol. 77, no. 11, pp. 1133-1139, 1998.

[14] B. E. Berg et al., "Routine analysis of hydrocarbons, PCB and PAH in marine sediments using supercritical $\mathrm{CO}_{2}$ extraction," Chemosphere, vol. 38, no. 3, pp. 587-599, 1999.

[15] C. Lutermann, W. Dott, and J. Hollender, "Combined modifier/in situ derivatization effects on supercritical fluid extraction of polycyclic aromatic hydrocarbons from soil," Journal of Chromatography, pp. 151-156, 1998.

[16] C. Lutermann et al., "Effects of various binary and ternary supercritical phases on the extraction of polycyclic aromatic hydrocarbons from contaminated soils," Journal of Chromatography, vol. 816, no. 2, pp. 201-211, 1998.

[17] S. B. Hawthorne et al., "Comparisons of Soxhlet extraction, pressurized liquid extraction, supercritical fluid extraction and subcritical water extraction for environmental solids: Recovery, selectivity and effects on sample matrix," Journal of Chromatography A, vol. 892, no. 1-2, pp. 421-433, 2000.

[18] P. Hallgren et al., "easuring bioavailability of polychlorinated biphenyls in soil to earthworms using selective supercritical fluid extraction," Chemosphere, vol. 63, no. 9, pp. 1532-1538, 2006.

[19] T. Nilsson et al., "Selective supercritical fluid extraction to identify aged sediment-bound PCBs available for uptake by eel," Environmental Pollution, vol. 140, no. 1, pp. 87-94, 2006.

[20] S. Sporring et al., "Comprehensive comparison of classic Soxhlet extraction with Soxtec extraction, ultrasonication extraction, supercritical fluid extraction, microwave assisted extraction and accelerated solvent extraction for the determination of polychlorinated biphenyls in soil," Journal of Chromatography, pp. 1-9, 2005.

[21] T. Nilsson and E. Björklund, "Selective supercritical fluid extraction as a tool for determining the PCB fraction accessible for uptake by chironomid larve in a limnic sediment," Chemosphere, vol. 60, no. 1, pp. 141-146, 2005.

[22] W. Zhou et al., "Polychlorinated biphenyl (PCB) partition equilibrium between St. Lawrence River sediments and supercritical fluids," The Journal of Supercritical Fluids, vol. 29, no. 1-2, pp. 31-42, 2004.

[23] E. Reverchon and I. Marco, "Supercritical fluid extraction and fractionation of natural matter," The Journal of Supercritical Fluids, vol. 38, no. 2, pp. 146-166, 2006.

[24] C. Gonçalves et al., "Optimization of supercritical fluid extraction of pesticide residues in soil by means of central composite design and analysis by gas chromatography-tandem mass spectrometry," Journal of Chromatography, pp. 6-14, 2006.

[25] C. Quan et al., "Supercritical fluid extraction and clean-up of organochlorine pesticides in ginseng," The Journal of Supercritical Fluids, vol. 31, no. 2, pp. 149-157, 2004.

[26] R. Jaffé et al., "High temperature supercritical carbon dioxide extractions of geological samples: Effects and contributions from the sample matrix," Applied Geochemistry, vol. 15, no. 1, pp. 79-89, 2000.

[27] P. Horvatovich et al., "Supercritical fluid extraction of hydrocarbons and 2-alkylcyclobutanones for the detection of irradiated foodstuffs," Journal of Chromatography, vol. A897, no. 1-2, pp. 259-268, 2000.

[28] M. O. P. Crespo and M. A. L. Yusty, "Comparison of supercritical fluid extraction and Soxhlet extraction for the determination of aliphatic hydrocarbons in seaweed samples," Ecotoxicology and Environmental Safety, vol. 64, no. 3, pp. 400-405, 2006. 
[29] A. Akinlua et al., "Supercritical fluid extraction of aliphatic hydrocarbons from Niger Delta sedimentary rock," The Journal of Supercritical Fluids, vol. 45, no. 1, pp. 57-63, 2008.

[30] I. Okamoto et al., "Effect of supercritical $\mathrm{CO} 2$ as the organic solvent on cap rock sealing performance for underground storage," Energy, vol. 30, no. 11-12, pp. 2344-2351, 2005.

[31] R. J. Hwang and J. Ortiz, "Mitigation of asphaltics deposition during $\mathrm{CO}_{2}$ flood by enhancing $\mathrm{CO}_{2}$ solvency with chemical modifiers," Organic Geochemistry, vol. 31, no. 12, pp. 1451-1462, 2000.

[32] Z. M. Liu et al., "Phase equilibria of the CO2-jiangsu crude oil system and precipitation of heavy components induced by supercritical $\mathrm{CO}_{2}$," Journal of Supercritical Fluids, vol. 16, pp. 27-31, 1999.

[33] A. H. Al-Marzouqi et al., "Supercritical fluid extraction for the determination of optimum oil recovery conditions," JPSE55, pp. 37-47, 2007.

[34] W. R. Ucok et al., "The extraction of hydrocarbon from crude oil by high pressure $\mathrm{CO}_{2}$, paper SPE 39684," presented at 1998 SPE/DOE Improved Oil Recovery Symposium, Tulsa, Oklahoma, April 1998.

[35] F. I. Stalkup, Miscible Displacement, SPE Publication, New York, pp. 137-146, 1983.

[36] J. Neter et al., Applied Linear Statistical Models, IRWIN, 4th edition, pp. 776-938, Chicago, USA, 1996.

[37] J. W. King and G. R. List, Supercritical Fluid Technology in Oil and Lipid Chemistry, The American Oil Chemists Society Press, Champaign, IL, USA, 1996.

[38] M. Meskar et al., "Optimization of operational parameters of supercritical fluid extraction forPHCs removal from a contaminated sand using response surfacemethodology," Journal of Environmental Chemical Engineering, vol. 6, 2018, pp. 3083-3094, 2018.

Copyright $\odot 2019$ by the authors. This is an open access article distributed under the Creative Commons Attribution License which permits unrestricted use, distribution, and reproduction in any medium, provided the original work is properly cited (CC BY 4.0).

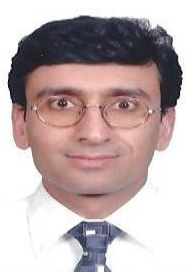

Ali Al-Marzouqi obtained his B.Sc. degree from University of Washington and his Ph.D. degree from Oregon State University. He has being working at the Chemical and Petroleum Engineering Department of UAE University since September 2000. Dr. Al-Marzouqi has served as the assistant dean for research and graduate studies in the College of Engineering for 12 years until he was appointed as the vice dean of the College of Graduate Studies in 2017. His research focuses on the use of supercritical fluid technology in food and pharmaceutical applications, biodiesel production, $\mathrm{CO}_{2}$ capture, brine management, and the conversion of biomass to high value chemicals. Dr. Al-Marzouqi has published over 110 journal and conference papers.

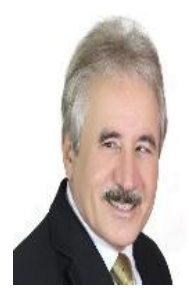

A. Y. Zekri received his B.Sc., M.S., and Ph.D. degrees from the University of Southern California. He has spent more than two decades in the petroleum industry. Professor Zekri worked as a consultant to the management committees of Waha Oil Co., and Agip Oil Company. He has authored and/or co-authored more than 90 papers on new developments and technical issues in the areas of improved oil recovery, flow through porous media, and environmental aspects of petroleum production, petroleum contracts, and enhanced oil recovery.

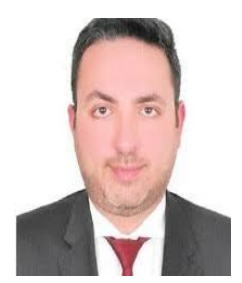

Adel Azzam obtained the bachelor's degree, science (chemistry), UAEU 2001 and the master degree, environmental sciences, UAEU 2009. Mr. Azzam is a senior consultant EHS (environment, health and safety, environment) at Ethos Integrated Solutions LLC Vereinigte Arabische Emirate.

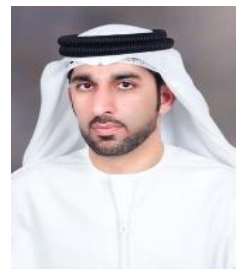

Abdulrahman Alraeesi earned his B.Sc. degree from United Arab Emirates University and MSc and $\mathrm{PhD}$ degrees from Colorado School of Mines, Golden, USA. He is an assistant professor of chemical engineering and served as a chair of the Chemical and Petroleum Engineering Department at College of Engineering, UAEU 2014-2018. He was appointed as the director of Emirates Center for Energy and Environment at UAEU in 2017. Dr. Alraeesi was an active member in UAEU council in the period of 2011 until 2013, and recently he is in the ADNOC R\&D Management Committee, Abu Dhabi Polytechnic Industrial Advisory Board for Petroleum Technology Program, and the UAE Armed Forces Innovation Evaluation Committee. His research interest is in inorganic palladium-based catalytic membrane reactors and Hydrogen related processes, membrane fabrication, and oil spill removal and adsorbents regeneration. 